\title{
Transaction costs perspective analysis of citizen participation policy
}

\author{
ZouJun \\ College of Humanities \\ Anhui Polytechnic University \\ Wuhu, China \\ e-mail: zoujun520@163.com
}

\author{
Hu YunFeng \\ College of Humanities \\ Anhui Polytechnic University \\ Wuhu, China \\ e-mail: imfbi@163.com
}

\begin{abstract}
Citizen participation in governance has become incr easingly important and citizen participation in public policy pr ocess is citizen participation in governance of the concentrated expression. Since the policy of the government and citizens to $p$ articipate in good, then why in reality the government and citiz ens will be a "dilemma" of the situation? One important reaso $n$ is the existence of transaction costs. Articles from transaction cost economics point of view, the policy of citizens involved in $t$ he transaction by building models, analysis of what is obtained in the internal market transactions or in the external market pl ace, depends crucially on the size of transactions. Transaction c osts in the public policy activities, widespread and can not disa ppear, but it can be controlled and reduced. Articles based on $t$ he model and proposed to build a sound system of citizen parti cipation, actively nurture and develop "intermediary organizat ions" on the policy. Segment in the market for policy, and incr ease in asset-specific investment policy and other policy recom mendations.(Abstract)
\end{abstract}

Keywords-government; citizen participation; public policy; tra nsaction costs (key words)

\section{INTRODUCTION}

Citizen participation in public policy issues important $\mathrm{p}$ ractical issues of concern in the current government and aca demia. Public policy has a dual property, both government i mplemented a means of public administration, government $\mathrm{s}$ ervices products - public goods. Under the conditions of mar ket economy, with the separation of government and enterpr ises, government and the market, government and society, $\mathrm{s}$ ocial diversification of autonomy, the role of government $i$ $\mathrm{n}$ the public policy process also quietly changed, citizen part icipation in public policy process to become an inevitable op tion. As a public policy "production" costs, market activity i $n$ the economic field, you can use the transaction cost theor $\mathrm{y}$ analysis, the same transaction costs in political activities is also wide spread. At present, most Chinese scholars from $\mathrm{p}$ olitical science or management theory analysis of the reason ableness and necessity of the public policy citizen participati on, many participate in ways and means; lack of research bu $t$ the transaction costs for citizens to participate in public pol icy issues, why the Government and citizens Policy Particip ation is often misunderstanding and bias, and even lead to ci vic policy to participate in a "phantom"?

\section{TRANSACTION COSTS AND CITIZEN POLICY PARTICIPATION}

\section{A. Transaction costs exist in reality Citizen Policy Participation}

Citizen participation in public policy formulation, imple mentation, evaluation and exit the course of this series ar e a large number of transaction costs, as in the economic sph ere, no friction "zero transaction costs," the world as positiv e transaction costs in the political sphere often unrealistic i s "normal", along with even more efficient than the economi c field loss. Political transaction costs is consuming resource $\mathrm{s}$ in the exchange of rights in the political market. Informati on asymmetry, opportunism and asset specificity leads to th e generation of political transaction costs ${ }^{[1]}$.

In the new institutional conomics, enterprise exists is beca use in between the market and the enterprise, companies ca $\mathrm{n}$ reduce transaction costs. Coase, in its nature, "a book on $t$ he analysis of the nature of the business, the nature of the en terprise is the alternative markets in order to save transactio $\mathrm{n}$ costs, to build abridge between the enterprise and the mark et. Coase argued, created the company to become profitabl e main reason seems to be that: there is the cost of using the price mechanism. "This cost can be summed up as many fac tors: (a) found that the cost of the price, and (b) to negotiate and conclude contracts costs ${ }^{[2]}$.Williamson believes that th e existence of transaction costs depends on three factors: the restricted rational thinking, opportunism and asset specificit $\mathrm{y}^{[3]}$.Transaction costs and no party has a monopoly of violen ce in the real world, the political and economic decision-ma king will inevitably interrelated ${ }^{[4]}$.The transaction costs of c itizen participation in the public policy process, from the ma in point of view can be divided into the cost of governmen t costs and civil government to attract and organize citizen $p$ articipation to pay administrative costs, while the citizens ha ve to pay the necessary costs of participation, including th e cost of learning time costs, negotiating costs and opportuni ty costs, etc.; From the stage of policy participation can be d ivided into participation in policy-making costs and particip ation in policy implementation, the amendment, the cost $o$ $\mathrm{f}$ monitoring and evaluation, citizen participation in the publ ic policy process at every stage of the transaction costs, an $d$ because of the quality and effectiveness of the policy in ea ch stage of the transaction costs vary widely; Explicit and i 
mplicit costs can be divided into from the the available obse rvational point of view of the transaction costs, some of th e citizens to participate in the transaction costs caused direct ly involved comparing apparent, easy to observe and measur e, and some citizens to participate in the transaction costs ar e indirectly produce relevant policy interests of the impact $\mathrm{i}$ s not timely show but recessive.

\section{B.Transactioncosts under different governance philosophy Citizen Policy Participation}

Control type governance thinking, transaction costs, an $\mathrm{d}$ the participation of citizens policy is contradictory, mutual restraint. The high efficiency of modern administrative requ irements of public policy, public administration, public req uirements policy process of democratization and transparenc y. Control-oriented government seems to exclude citizen par ticipation in government independent formulate policies will be time-consuming shorter, lower cost, higher efficiency. T he breadth and depth of citizen participation may make the $g$ overnment administrative costs and participation to some ex tent proportional to the rising cost. This stage, citizen partici pation enthusiasm generally not high, government to seek a high support rate policy, must take into account the attitude and with the extent of the citizens. High support rate polic $\mathrm{y}$ brought the government cost to use a lot of persuasion to $\mathrm{c}$ onvince the citizens to participate in the policy process, th e government and citizens of the negotiation process involve s negotiations and opportunity costs. We support rate of acc eptance of the policy, the higher the rate of support, the high er the degree of recognition of the policy, on the contrary, th e low level of acceptance of the policy, can not be effectivel y implemented. Thus, we can see that the lower support rat e, the smaller the transaction costs; Conversely, you need a l arger transaction costs. Cost increase means that the reducti on of administrative efficiency. Practice has proved that citi zen participation in the West, "citizen participation directly affects the efficiency and quality of public decision-makin g and public policy." Any one policy is quality consideratio ns, such as technical constraints, regulatory constraints, secu rity constraints, budget constraints, especially for those who need the expertise and technology policy, civic participation may lead to standards and constraints are ignored, so the eff iciency and quality of the policy suffered huge losses. In add ition, citizen participation will block reform and innovation. The breadth of citizen participation has also increased the po ssibility of the the vetoed reform program or forcing compro mise, broad participation of citizens, may hinder the develop ment and implementation of the policy of reform-style, whic $\mathrm{h}$ may lead to the society before the stoppage, the lack of vit ality $^{[5]}$.From this point of view, it seems that the citizens' par ticipation in public policy will affect administrative efficien cy, then the citizens to participate in public policy will beco me meaningless.

However, under the governance concept in service-orie nted government, transaction costs and citizenship policy pa rticipation can be mutually reinforcing. Traditional governm ent management thinking, ignoring the independent policie s of the government due to the lack of public support, and le ad society in favor of low, then the policy will be resisted $i$ $\mathrm{n}$ the execution process, ineffective, resulting in transaction costs by society as a whole, social welfare losses; policy pro cess will be to rethink this new policy process will lead $t$ o a series of rising cost, the so-called "chop and change "pol icies, under the measures "is a true portrayal of the phenome non. Actual political life, people tend to fall into a vicious ci rcle: the passive citizen participation, the more the pursuit o $\mathrm{f}$ citizen participation, pay higher transaction costs, administ rative efficiency will be getting lower and lower, which in tu $\mathrm{rn}$ prompted the government increasingly seeking one-way $\mathrm{d}$ ecision-making, which in turn exacerbate the low administra tive efficiency, so that people will naturally inefficient attrib uted to too many. Citizen support is a prerequisite for effecti ve implementation of the policy. The degree of policy suppo rt directly determine the effect of policy implementation, ine fficient hinder citizen participation "excuse" or that citizen $\mathrm{p}$ articipation is not thorough enough citizens to participate. In creasingly proactive political participation of citizens in th e governance of service oriented and usually, the governmen $t$ no longer needs to provide the additional cost of participati on. At the same time, the government also will depend on ci tizen participation as a matter of course, the transaction cost $\mathrm{s}$ will be greatly reduced. Because of the broad participatio $\mathrm{n}$ of the citizens, the time spent in the process of policy form ulation or execution will greatly reduce the opportunity cost s also dropped significantly, citizen support of the policy rat e continues to increase, the government will no longer need to repeat the policy process. In this case, the citizens to parti cipate more and more widely, participate in an orderly scien tific increasing government will become easier in the gras p of public opinion, this will not bring about the increase i $\mathrm{n}$ transaction costs, but significantly increase the Governme nt's administrative efficiency. In a service-oriented governm ent, all government actions and civil behavior becomes obse rvable opportunistic behavior is greatly reduced, the will of $t$ he citizens are more easy to grasp. Policy objectives is beco ming clearer, the policy participation also will be more conv enient and science, the government no longer worry about tr ansaction costs. Therefore, more citizen participation in th e public policy process, the higher the rate of policy suppor $\mathrm{t}$, but gradually reduce transaction costs.

\section{INEFFICIENT POLICY PARTICIPATION OF OUR CITIZENS}

\section{A. System lags behind}

In the Perspective of New Institutional Economics, the i mpact of the system on the socio-economic and political, the ever-present, everywhere. The system specification is missi ng, cause of Citizen Policy Participation disorderly and ineff icient, high transaction costs. China has such "Petition Regu lations”, "Open Government Information Regulations of th e People's Republic of China "and other laws and regulation $\mathrm{s}$ to protect the citizens' right to know the provisions of the $r$ 
ight to participate, but is still only in specialized legal terms of some of the provisions, is still missing specialized laws a nd regulations to protect citizens' participation. With econo mic development, Citizen Policy Participation demand is gr owing, and our encouragement and protection of citizens to participate in the construction of rules and regulations is ind eed serious lag Citizen Policy Participation rattling around li ke headless flies not only affect the participation performanc $\mathrm{e}$, and increased transaction costs.

\section{B. Development of social groups, such as "intermediary organizations"}

Previous analysis, we will participate in the market polic $y$ is divided into Government of the internal market and th e external market of the citizens, and the policy process is $\mathrm{w}$ hat is to resolve the internal market or through external mar ket solution depends entirely on the citizens to participate i $\mathrm{n}$ the deal size. The introduction of a public policy will invol ve the adjustment of interests, our attention must be paid to $t$ he "voice" of interest groups. These needs through intermed iary organizations to play a role ordinary individual citizen $\mathrm{v}$ iews on policy issues is often fragmented, one-sided, and a $\mathrm{v}$ ariety of intermediary organizations often effective citizens ' personal opinions into consistent, clear organization view $\mathrm{s}$, and with the power of "intermediary organizations" to sen $\mathrm{d}$ a clear interest demands to government departments. Chi na citizen participation is often manifested between govern ment and citizens directly to the game, the lack of "middl e market" transition, they often result in citizen participatio $\mathrm{n}$ scale difficult to control, the government as finite rational people often consider from a cost-benefit point of view, led $t$ o the Government subjective tends boycott or restrict citizen participation.Seriously lagging behind the development of $i$ ndependent civil society in China, many civil society group $\mathrm{s}$ attached to governmental organizations, difficult to indepe ndently express their views, not high degree of trust in the ci tizens, civic policy involved in the transaction size is difficu lt to control, high transaction costs, leading to the governme nt policy to participate "internal" serious tendency, so that th e citizens of policy involvement often a mere formality.

\section{Bounded rationality and opportunistic behavior Citizen $P$ olicy Participation costs}

Government and citizen cooperation, limited rationalit $\mathrm{y}$ and opportunistic behavior greatly increased the transactio $\mathrm{n}$ costs of policy participation of citizens. Government polic $\mathrm{y}$-makers is not possible to accurately predict and determin e the various possible changes, therefore the current policy p rogram has a certain degree of incompleteness. Policy proce ss exist prior conflict of interests (preferences and constraint $\mathrm{s}$ before policy makers inconsistent) and after the conflict of interest (the policy has led to the pattern of distribution of $b$ enefits generated distributive conflicts of interest), prior inc onsistent can negotiate to form a consensus, but after the co nflict is difficult to passsolve beforehand, the participants re cognized that it may not fully beforehand commitments, lea ving space for future breach ${ }^{[5]}$. Therefore, the ex post opport unism is not only the distribution of wealth, but also a loss o $\mathrm{f}$ efficiency ${ }^{[6]}$. Bounded rationality and opportunistic behavi or greatly increased the complexity of Citizen Policy Partici pation led to greatly improve the transaction costs.

\section{Unsound policy market}

General product markets for different products take diffe rent trading ways and means to reduce transaction costs, th e same public policy public product attributes, different poli cies "product" market, to take a different participation ways and means, but also conducive reduce the transaction costs o $\mathrm{f}$ policy participation. At present, China's policy market is $n$ ot perfect, is typical of the government-led policy market, th e citizens of the government-led governance policies involv ed in the allocation of resources, often resulting in inefficien $\mathrm{t}$ allocation of resources, rising costs, "supply and demand " prominent. Government policy participation tend to be bro ken down because of bounded rationality and opportunis $\mathrm{m}$, not policy market and provide a participatory approach, a single pathway. So prone to the two extreme cases, or the la ck of participation, a mere formality; either involved in larg e-scale involved in disorderly confusion expensive transacti on costs, both cases will eventually lead to the Citizen Polic y Participation inefficient, resulting in a "lose-lose" situation.

\section{E. Lack of government investment}

The theory of transaction cost economics, asset specifi city is an important factor in the transaction costs. Enterpris e product market prior specific assets investment may produ ce a bilateral monopoly cause opportunistic behavior after th e fact "rip-off". By the preceding analysis, the degree of part icipation of the policy depends on the size of the transactio $\mathrm{n}$ and the transaction costs. Certain specific assets help to re duce transaction costs, create economies of scale. Dedicate $\mathrm{d}$ more assets will increase uncertainty, because the observat ion becomes difficult, but the view of Citizen Participatio n, Citizen Policy Participation dedicated inputs are not hig $\mathrm{h}$ but too little, leading citizens of policy involved in the ent husiasm is not high, the effect is not good, mainly due to: fir st, the government attract participation commitment not cred ible. Policies involved in the investment in dedicated assets 1 ess citizen participation is temporary, just going through the motions, and thus are not enthusiastic; participate in a single channel instability, leading to high cost of participation.

\section{IV. .ENHANCE CITIZENS' POLICY TO PARTICIPATE IN THE PERFORMANCE OF POLICY RECOMMENDATIONS}

\section{A. The perfect citizen participation system construction}

China must vigorously sound system of citizen participati on in security system, to enable citizens to participate in th e rule-based, lower the cost of the policy involved in the neg otiations. We can carry out system construction from the fol lowing aspects: first, to improve laws and regulations. There fore, China should establish a special citizens to participate i 
$\mathrm{n}$ the laws and regulations of specific provisions on the scop e of citizen participation, approaches, organizational method $\mathrm{s}$ and responsible departments, so that the government and $\mathrm{t}$ he citizens are rules to avoid unnecessary efficiency loss, re duce transaction costs. Second, to strengthen the supervisio $\mathrm{n}$ system of the policy process. Policy participation of citize ns is not only reflected in the formulation of public policy, $r$ eflected in the process of policy implementation, adjustmen $\mathrm{t}$, monitoring, and evaluation of a series of citizens' participa tion in this series in the policy process must rely on a compr ehensive monitoring system to achieve. The government mu st speed up the establishment of an effective monitoring syst em, easy to find problems, information published to provide services for citizen participation, so that the flow of informa tion and timely response. Government supervision system pl ay a role in providing policy information, save citizen's infor mation discovery and search costs, help increase citizen part icipation enthusiasm and initiative.

B. "Intermediary organizations" actively nurture and develop the construction of the citizens to participate in the "middle market"

Government should change their concepts, and actively nurture and development of intermediary organizations, inc luding civil society, non-governmental organizations (NGO s), community-based organizations, and interest groups. Soc iety participation in essence is the mode of a group involved in the policy process ${ }^{[7]}$. "Intermediary organizations" with a certain scale political deal, it will become a channel of com munication between the government and citizens and bridge, citizens of different interest demands can be expressed in di fferent "intermediary organizations", the formation of a polit ical deal with the "middle market in the middle of the marke t stakeholders will the game, and in the process the governm ent can save a lot of negotiating costs, time costs, and opport unity costs, and so on, so that the citizen Policy Participatio $\mathrm{n}$ transaction size dispersed in various middle market, which help control the over all size of the transaction, to avoid citi zen participation Chief "internal", and also help to reduce th e transaction costs to improve civic policy involved in the $p$ erformance, government and citizens to achieve a "win-win".

\section{C.Transparent policy processinformation, and to prevent op portunistic behavior}

Through the policy of former citizens to participate in th e analysis of the market model, we can see how in transactio $\mathrm{n}$ costs is the real world, the government of the participation of civil policy administration "internal" tendencies, but th e government and citizen cooperation is still possible. Mini mum degree of voluntary cooperation in the social life is no $\mathrm{t}, 100 \%$ of the dictatorship, that completely dominant social costs are too high ${ }^{[8]}$. Effective social cooperation is possibl e, because people will gain experience from the real worl $\mathrm{d}$, more people will realize that they have common interest $\mathrm{s}$, cooperative behavior is also reciprocal ${ }^{[9]}$. Trading marke $t$ in terms of policy, in the face of opportunistic behavior, th e best preventive measure is to increase the transparency of $t$ he policy process, full disclosure of information to the partie $\mathrm{s}$ to the transaction, so that information symmetry. In the cas e of asymmetric information (ie, the negotiating parties wit $\mathrm{h}$ private information), the result of inefficient will appear. (kreps,1990) ${ }^{[10]}$. The purpose of the market is effective or ganizational transactions, but if the parties to the transactio $\mathrm{n}$ is a lack of good faith, to hide information, it will make th e transactions costs are very high maintenance and sanctions, and thus will result in the loss of opportunities for cooperati on, market inefficiencies. Citizen Policy Participation must ensure that the whole process of open and transparent infor mation to prevent opportunistic behavior.

\section{ACKNOWLEDGMENT}

This paper is suppoted by 2012 national college student $\mathrm{s}$ innovative entrepreneurial training projects. Item number $\mathrm{i}$ s 201210363181.

\section{REFERENCES}

[1]Huang Xinhua. Economic Analysis of Political Transactions: A Review of Contemporary Western Theory of Transaction Cost Politics. Jouranal of Xiamen University( Arts \& Social Sciences),2009(5).(references)

[2][3]Michael Dietrich. Transaction Cost Economics And Beyond. Beijing: Economics Science Press,1999.p21,p29.(references)

[4][6][8][9] Furubotn,E,G,,Richter,R.. New Institutional Economics: A par adigm of transaction cost analysis. Shanghai: Shanghai People's Press.2006. p27,p534,p139,p392.(references)

[5]Zhou Yean, Bao Linmei. Commitment and Analyzing the Efficiency of Economic Policies. Teaching and Research,2005(4).(references)

[7]Sun Yongyi. China's Ten dilemma in Process of Citizen Participation in Public Ppolicy. Chinese Public Administration,2006(1).(references)

[10]Kreps,D.M.. A course in Microeconomic Theory. New York: Harvers ter,1990.p760.(references)

[11]He Zhe. The Boundaries of Democracy and Centralism----A new Syste m Based on Transaction Cost Economics Perspective. Admemics, 2011(3).

[12]Luo Chongpu. Citizen participation strategies to resolve difficulties. Information of Economics and Law, $20 \quad$ 08(5).

[13]Wang Wei, Tang Xingzhi. Transaction costs perspective to think of the cost of government operations. Administrative Tribune,2009(4). 